\title{
Riociguat and cinaciguat exert no direct effects on contractility and relaxation of cardiac myocytes from normal rats
}

\author{
Yvonne Reinke ${ }^{1,4}$, Stefan Gross ${ }^{1,4}$, Lars G Eckerle ${ }^{1}$, Isabel Hertrich ${ }^{1}$, Mathias Busch 1 , Raila Busch ${ }^{1,4}$, Alexander Riad ${ }^{1,4}$, \\ Bernhard H Rauch', Johannes-Peter Stasch ${ }^{3}$, Marcus Dörr ${ }^{1,4}$, Stephan B Felix ${ }^{1,4^{*}}$
}

From 7th International Conference on cGMP Generators, Effectors and Therapeutic Implications

Trier, Germany. 19-21 June 2015

\section{Clinical background}

In the clinical setting, administration of organic nitrates and nitric oxide (NO) donors has serious limitations such as resistance to $\mathrm{NO}$ and organic nitrates due to insufficient biometabolism and development of tolerance following prolonged administration of $\mathrm{NO}$ soluble guanylate cyclase (sGC) to NO [1,2]. This circumstance has led to development of heme-dependent sGC stimulators and heme-independent sGC activators. The sGC stimulator riociguat and the sGC activator cinaciguat have been shown to induce various beneficial effects in both experimental and clinical research. Any direct dosedependent effects of these compounds on cell contraction and relaxation of isolated cardiac myocytes, however, remain to be elucidated [3].

\section{Methods and results}

We analyzed the dose-dependent effects of the sGC stimulator riociguat and the sGC activator cinaciguat at clinical relevant concentrations $\left(10^{-10}-10^{-5} \mathrm{~mol} / \mathrm{L}\right)$ on contraction, relaxation, and calcium transients of isolated field-stimulated cardiac myocytes from healthy rats - in comparison to the $\beta$-adrenoreceptor agonist isoproterenol $\left(10^{-9}-10^{-5} \mathrm{~mol} / \mathrm{l}\right)$, the calcium channel blocker verapamil $\left(10^{-9}-10^{-5} \mathrm{~mol} / \mathrm{L}\right)$, and the cell permeable cGMP-analog 8-(4-Chlorophenylthio)-guanosine3',5'cyclic monophosphate (8-pCPT-cGMP; $10^{-9}-10^{-6} \mathrm{~mol} / \mathrm{L}$ ). Isoproterenol induced a dose-dependent significant increase in cell contraction, contraction velocity, relaxation velocity, and calcium transients, whereas verapamil

\footnotetext{
* Correspondence: felix@uni-greifswald.de

${ }^{1}$ Department of Internal Medicine B, Cardiology, University Medicine

Greifswald, Germany

Full list of author information is available at the end of the article
}

significantly decreased these parameters. On the other hand, 8-pCPT-cGMP induced a negative inotropic effect at $10^{-5} \mathrm{~mol} / \mathrm{L}$ accompanied by a slight increase in relaxation velocity. In contrast, neither riociguat nor cinaciguat significantly influenced all measured parameters. Furthermore, we determined the immediate effect of riociguat and cinaciguat on cGMP and cAMP production in isolated rat cardiac myocytes. Whereas the cAMP signaling cascade was influenced neither by riociguat nor by cinaciguat, both compounds (at $10^{-6} \mathrm{~mol} / \mathrm{L}$ ) significantly increased intracellular cGMP generation. Moreover, this accumulation was significantly augmented by cinaciguat in the presence of the sGC inhibitor $1 \mathrm{H}-[1,2], 4$ Oxadiazolo [4,3-a] quinoxalin-1-one (ODQ, $25 \mu \mathrm{M})$ whereas ODQ blocked cGMP generation by riociguat. However, blocking of sGC did not influence cell contractility.

\section{Conclusion}

Our data revealed that an increase in cGMP levels induced by riociguat and cinaciguat at clinical relevant concentrations is not associated with acute direct effects on cell contraction and relaxation in isolated cardiac myocytes from healthy rats.

\section{Authors' details \\ 'Department of Internal Medicine B, Cardiology, University Medicine Greifswald, Germany. ${ }^{2}$ Department of Pharmacology, Ernst Moritz Arndt University, Ernst-Moritz-Arndt-University of Greifswald, Germany. ${ }^{3}$ Cardiology Research, Bayer Pharma AG, Wuppertal, Germany, Institute of Pharmacy, Martin Luther-University Halle-Wittenberg, Germany. ${ }^{4}$ DZHK (German Centre for Cardiovascular Research), partner site Greifswald, Germany.}

Published: 2 September 2015 


\section{References}

1. Evgenov OV, Pacher P, Schmidt PM, Hasko G, Schmidt HH, Stasch JP: NOindependent stimulators and activators of soluble guanylate cyclase: discovery and therapeutic potential. Nat Rev Drug Discov 2006, 5(9):755-768.

2. Stasch JP, Pacher P, Evgenov OV: Soluble guanylate cyclase as an emerging therapeutic target in cardiopulmonary disease. Circulation 2011, 123(20):2263-2273.

3. Hammond J, Balligand JL: Nitric oxide synthase and cyclic GMP signaling in cardiac myocytes: from contractility to remodeling. J Mol Cell Cardiol 2012, 52(2):330-340

doi:10.1186/2050-6511-16-S1-A77

Cite this article as: Reinke et al:: Riociguat and cinaciguat exert no

direct effects on contractility and relaxation of cardiac myocytes from normal rats. BMC Pharmacology and Toxicology 2015 16(Suppl 1):A77.

\section{Submit your next manuscript to BioMed Central} and take full advantage of:

- Convenient online submission

- Thorough peer review

- No space constraints or color figure charges

- Immediate publication on acceptance

- Inclusion in PubMed, CAS, Scopus and Google Scholar

- Research which is freely available for redistribution

Submit your manuscript at www.biomedcentral.com/submit
C Biomed Central 